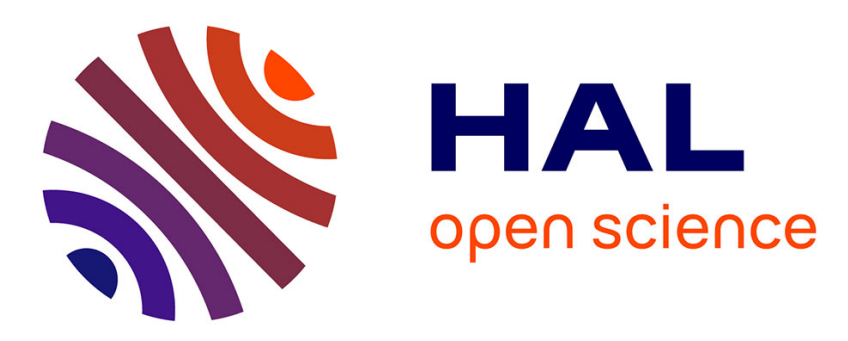

\title{
Advanced mine restoration protocols facilitate early recovery of soil microbial biomass, activity and functional diversity
}

Benjamin R Waterhouse, Karen L Adair, Stéphane Boyer, Steve D Wratten

\section{- To cite this version:}

Benjamin R Waterhouse, Karen L Adair, Stéphane Boyer, Steve D Wratten. Advanced mine restoration protocols facilitate early recovery of soil microbial biomass, activity and functional diversity. Basic and Applied Ecology, 2014, 15 (7), pp.599-606. 10.1016/j.baae.2014.09.001 . hal-02303663

\section{HAL Id: hal-02303663 https://hal.science/hal-02303663}

Submitted on 2 Oct 2019

HAL is a multi-disciplinary open access archive for the deposit and dissemination of scientific research documents, whether they are published or not. The documents may come from teaching and research institutions in France or abroad, or from public or private research centers.
L'archive ouverte pluridisciplinaire HAL, est destinée au dépôt et à la diffusion de documents scientifiques de niveau recherche, publiés ou non, émanant des établissements d'enseignement et de recherche français ou étrangers, des laboratoires publics ou privés. 


\section{Accepted Manuscript}

Title: Advanced mine restoration protocols facilitate early recovery of soil microbial biomass, activity and functional diversity

Author: Benjamin R. Waterhouse Karen L. Adair Stéphane Boyer Steve D. Wratten

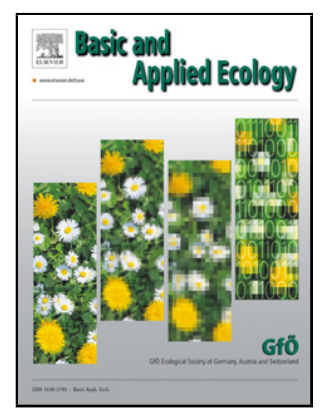

PII:

DOI:

S1439-1791(14)00114-5

Reference: http://dx.doi.org/doi:10.1016/j.baae.2014.09.001

To appear in:

Received date: $\quad 1-4-2014$

Revised date: 2-9-2014

Accepted date: $\quad$ 5-9-2014

Please cite this article as: Waterhouse, B. R., Adair, K. L., Boyer, S., and Wratten, S. D.,Advanced mine restoration protocols facilitate early recovery of soil microbial biomass, activity and functional diversity, Basic and Applied Ecology (2014), http://dx.doi.org/10.1016/j.baae.2014.09.001

This is a PDF file of an unedited manuscript that has been accepted for publication. As a service to our customers we are providing this early version of the manuscript. The manuscript will undergo copyediting, typesetting, and review of the resulting proof before it is published in its final form. Please note that during the production process errors may be discovered which could affect the content, and all legal disclaimers that apply to the journal pertain. 


\section{Advanced mine restoration protocols facilitate early recovery}

2 of soil microbial biomass, activity and functional diversity.

3

4 Benjamin R. Waterhouse ${ }^{* 1}$, Karen L. Adair ${ }^{1}$, Stéphane Boyer ${ }^{1,2}$ and Steve D. Wratten ${ }^{1}$ 5

$6 \quad{ }^{1}$ Bio-Protection Research Centre, PO Box 85084, Lincoln University, Lincoln, 7647,

$7 \quad$ New Zealand.

8

$9 \quad{ }^{2}$ Department of Ecology, PO Box 85084, Lincoln University, Lincoln 7647, New 10 Zealand.

* Corresponding author: Ben Waterhouse. Tel.: 0064423 0932; fax: 00643253864

Email address: brwaterhouse@gmail.com 
Abstract

Many ecosystem restoration programmes can take over 15 years to achieve ecosystem functioning comparable to that of an unmodified ecosystem, therefore a reliable shorter-term method of assessing and monitoring ecosystem recovery is needed to ensure that recovery is following an appropriate trajectory. Soil microbes respond to environmental change relatively quickly, and shifts in microbial communities can reflect the current status of their environment. As well as potentially acting as 'indicator communities', microbes play an integral role in restoring ecosystem functions. On an active opencast mine on New Zealand's West Coast, three main restoration methods are used, differing in cost and restoration effort. They range from most expensive 1) vegetation direct transfer (VDT), to 2) biosolids-amended stockpiles that are spread and replanted, and 3) untreated stockpiles that are spread and replanted. We assessed the impacts of these methods on soil microbial communities by measuring microbial biomass, dehydrogenase activity, community level physiological profile (CLPP) and functional diversity as measured by carbon substrate utilisation, where restored sites were 5 years old or less. These measures were compared to an unmodified reference ecosystem in the same location. Microbial activity and biomass were highest in pristine habitats, followed by VDT and biosolids-amended soils, then untreated stockpile soil. When compared to all other treatments untreated stockpiled soils had significantly different CLPPs and significantly reduced microbial biomass and activity; microbial biomass was an order of magnitude lower than in pristine soils. Functional diversity and richness did not differ between pristine, VDT and biosolids-amended soils, but 
were higher than in untreated stockpiled soils. CLPPs did not differ between pristine habitat soil and VDT soil but biosolids-amended and untreated stockpiled soils were significantly different to pristine soil. This study has shown that soil microbial communities are a valuable tool to assess restoration progress, and that ecosystem restoration can begin in a relatively short time following investment in appropriate restoration strategy, ultimately benefiting recolonisation by plants and animals.

\section{Zusammenfassung}

Viele Ökosystem-Renaturierungsprogramme können mehr als 15 Jahre benötigen, bevor eine Ökosystemfunktion, die mit der eines nicht modifizierten Ökosystems vergleichbar ist, erreicht wird. Darum wird eine verlässliche, früher einsetzbare Methode zur Bewertung und Überwachung der Regeneration des Ökosystems benötigt, um sicherzustellen, dass die Regeneration einen geeigneten Verlauf nimmt. Bodenmikroorganismen reagieren relativ schnell auf Umweltänderungen, und Änderungen der Mikroben-Gemeinschaften können den aktuellen Status ihrer Umwelt widerspiegeln. So wie sie potentiell als "Indikator-Gemeinschaften" fungieren, spielen Mikroben auch eine zentrale Rolle bei der Wiederherstellung von Ökosystemfunktionen. In einer aktiven Tagebau-Kohlegrube an der neuseeländischen Westküste werden drei Haupt-Renaturierungsmethoden angewandt, die sich hinsichtlich der Kosten und des Aufwandes unterscheiden. Sie reichen von der sehr teuren direkten Übertragung bewachsener Bodenblöcke (VDT) über die Ausbringung von mit Klärschlamm vermischtem Lagerhaldenmaterial, das ausgebreitet und bepflanzt wird, bis zur Ausbringung von unbehandeltem Haldenmaterial, das verteilt und bepflanzt wird. Wir erfassten die Auswirkungen 
dieser Behandlungen auf die Mikrobengemeinschaften im Boden, indem wir die mikrobielle Biomasse, die Dehydrogenase-Aktivität, das physiologische Profil der Gemeinschaften und die funktionelle Diversität (gemessen als Nutzung von verschiedenen Kohlenstoffsubstraten) bestimmten. Die untersuchten

Renaturierungsflächen waren bis zu fünf Jahre alt. Die Messungen wurden mit Daten aus einem benachbarten naturnahen Referenzökosystem verglichen. Die mikrobielle Aktivität und Biomasse waren in dem alten Ökosystem am höchsten, gefolgt von den VDT-Flächen, dem mit Klärschlamm versetzten Material und schließlich dem unbehandelten Haldenmaterial. Die letztgenannte Behandlung wies verglichen mit den anderen Varianten ein signifikant abweichendes physiologisches Profil sowie signifikant reduzierte mikrobielle Biomasse und Aktivität auf. Die mikrobielle Biomasse war um eine Größenordnung geringer als die von ursprünglichem Boden. Funktionelle Diversität und funktioneller Reichtum unterschieden sich nicht zwischen ursprünglichen, mit Klärschlamm gemischten und VDT-Böden; sie waren aber höher als in unbehandelten Haldenböden. Die physiologischen Profile der Gemeinschaften unterschieden sich nicht zwischen ursprünglichem Boden und VDT-Böden, aber sowohl mit Klärschlamm versetzter als auch unbehandelter Haldenboden unterschieden sich signifikant vom ursprünglichen Boden. Diese Untersuchung hat gezeigt, dass mikrobielle Gemeinschaften des Bodens ein wertvolles Mittel sind, um den Rekultivierungsfortschritt abzuschätzen und dass die Renaturierung relativ kurz nach der Investition in eine angemessene Renaturierungsstrategie einsetzen kann, wodurch letztendlich die Wiederbesiedlung durch Pflanzen und Tiere gefördert wird. 
87 Keywords: Biosolids; Ecological restoration; Microbes; Mining; Vegetation direct 88 transfer; VDT.

89

90 
Introduction

93 To access target resources, opencast mining requires the complete removal of soil, rock and vegetation, soil and rock mixtures are then regularly stored in large stockpiles of mixed topsoil and various other rock and soil strata (Boyer, Wratten, Pizey, \& Weber, 2011). In New Zealand, these stockpiles are often used for restoration of areas where mining is complete. However, the materials selected for stockpile storage (soil, subsoil and overburden) can have detrimental effects on stored soil quality, microbial communities and fauna. For example, increased proportions of rock and a reduction in levels of primary plant nutrients (Nitrogen $(N)$,

Phosphorus (P), Potassium (K) and Carbon (C)) in stockpile soil will decrease soil quality (summarised in Sheoran et al. 2010). Stockpiles can become stratified such that at $>1 \mathrm{~m}$ depth they can become compacted and anaerobic resulting in loss of earthworm populations (Boyer et al., 2011), decreased abundance of mycorrhizae, aerobic bacteria and fungal species, and an increase in soil bacterial to fungal ratio

106 (Abdul-Kareem \& McRae, 1984; Harris, Birch, \& Short, 1989).

108 Soil quality is important in the restoration of ecosystems because of its role as the physical, biological and nutrient basis for plant recolonisation and establishment

110 (Zhang \& Chu, 2012). Soil microbial communities are responsible for many

111 ecosystem functions including decomposition, nutrient cycling, nitrogen fixation and 112 soil formation (Zhang \& Chu, 2011). They also support revegetation processes, which 113 can further stabilize soils and prevent loss of bulk soil and nutrients through erosion 114 (Ros, Hernandez, \& García, 2003). Restoration following mining should therefore not 
only aim to achieve plant cover, but also regenerate soil functions that form the foundations on which ecosystems can persist (Ohsowski, Klironomos, Dunfield, \& Hart, 2012); and microbial assessments can contribute an insight to this process.

The definition of ecological restoration, as defined by the Society for Ecological Restoration, is: 'the process of assisting the recovery of an ecosystem... towards a reference state' (Society for Ecological Restoration, 2013). Following this definition, studies have shown that after mining, at least 15 years or more may pass before soil functions are comparable to those of pristine areas (Ruiz-jaen \& Aide, 2005; Grant \& Ward, 2007). While restoration of soil functions may take decades, monitoring in its early stages is essential to assess whether restoration efforts are effective or at least following a suitable trajectory, and that limited resources (time, finance, machinery) are not misdirected. Appropriate early monitoring can also be useful to assess the efficacy of new or previously untested restoration techniques.

The majority of restoration studies examining ecosystem processes occur within 15 years since restoration was implemented, with most of these in the first 5-10 years (Wortley, Hero, \& Howes, 2013). These studies show that some ecological processes can have made measurable progress within that time. In particular, soil microbial communities can serve as early indicators of effective mine restoration, because they respond relatively quickly to changes in environmental conditions (Sparling, 1992; Emmerling, Liebner, \& Haubold-Rosar, 2000; Izquierdo, Caravaca, Alguacil, Hernández, \& Roldán, 2005). They can provide more accurate representations of short-term recovery, unlike plant species diversity assessments that may prove 
139

140

141

142

143

144

145

146

147

150

151

152 Typically VDT contains low-medium height scrub vegetation (1-3 $\mathrm{m}$ in height) as

153 larger trees have root networks that become damaged by the process and

154 experience dieback. The second most labour-intensive restoration strategy is the

155 mixing of biosolids (dried and sterilised municipal sewage waste) with stockpiled

156 mine tailings, which are then spread and planted with native vegetation. The third

157 process is the spread of untreated stockpiled tailings, which are also replanted with

158 native species. VDT and biosolids soil amendments are relatively new additions to

159 the Stockton mine restoration protocols that have been implemented on a large

160 scale only within the last 5 years, and have not yet been thoroughly assessed for

161 their efficacy in restoring mined areas. To our knowledge few studies have assessed 
162

163

164

165

166

167

168

the role of VDT in ecological restoration (Simcock et al., 1999; Ross et al., 2000), and its impact on soil organisms (Boyer et al., 2011).

This study assessed soil microbial metrics under the three primary restoration techniques used on the mine less than five years after their deployment. This includes measurement of dehydrogenase activity, soil microbial biomass, functional diversity, and community-level physiological profiles (CLPP). These measurements were compared to those taken from local unmined native habitat as a benchmark for restoration success.

\section{Materials and methods}

\section{Experimental design and site selection}

Stockton mine has been active since 2008 with an expectancy of 20 years coal extraction. Prior to mining, the area was pristine native New Zealand bush vegetation, of typically low to medium height (1-5 $\mathrm{m})$ ranging from native tussock grassland to beech and podocarp forest. The site undergoing restoration following coal extraction was Mt Frederick, located on the southwestern area of the Stockton mine (414248.16 E, 1715045.03 S). Mt Frederick was selected as it was one of the first areas where mining had been completed. It contains a number of replicated restoration sites ( $n=4$ for all restoration types) of differing restoration techniques, including VDT (direct, never stored in holding sites), biosolids soil amendment, and 
untreated stockpiled soil spreads, and an unmodified pristine native site, all within

$0.5 \mathrm{~km}$ of one another. The inclusion of areas of unmodified native vegetation was

188 intended as a benchmark for the restored sites, and was the same state as that prior

189 to mining. Owing to their location, all sites were a similar size (approximately 200-

$190300 \mathrm{~m}^{2}$ ), and were subject to similar environmental variables such as slope and

191 weather conditions at a west to southwest orientation of approximately $1000 \mathrm{~m}$

192 altitude. Age ranges for restored sites were: VDT 2-5 years, replanted stockpiled soils

$1932-5$ years, and biosolids treated stockpiled soils 3-4 years. Soil stockpiles contain soil,

194 small fractured rock (generally $<5 \mathrm{~cm}$ in diameter) and overburden, and can range

195 from 6 months to 5 years in age before use. Standard practice on Stockton mine is to

196 1:1 mix 5 years stockpiled soil with 6 months stockpiles prior to spreading and

197 planting in an attempt to improve soil quality (Thompson, personal communication).

198 The biosolids spread comprises 1:4 mix of biosolids and the above described

199 stockpiled soil preparation.

200

201

202

Soil collection

203

204 Soils were collected from four separate plots of each restoration type. Fifty $7 \mathrm{~cm}$

205 deep $\times 3 \mathrm{~cm}$ wide soil cores were taken across each restored and pristine plot

206 starting in one corner of the plot and following a ' $Z$ ' shaped path across the width

207 and length of the plot to capture the variation in soils within each plot. The 50 cores

208 were then pooled for each site. Soil was then transported to Lincoln University, New

209 Zealand and stored at $4{ }^{\circ} \mathrm{C}$ until microbial assays were completed. 
Soil microbial biomass

213

214 Microbial biomass was assessed by the chloroform-fumigation method (Vance,

215 Brookes, \& Jenkinson, 1987). Triplicate $3.5 \mathrm{~g}$ soil fresh weight subsamples were

216 extracted in $15 \mathrm{ml} 0.5 \mathrm{M} \mathrm{K}_{2} \mathrm{SO}_{4}$ (at 1:4 soil:extractant ratio) for 30 minutes on a rotary

217 shaker. Extracts were filtered using Whatman № 40 filter paper and analysed on a

218 Total Organic Carbon Analyser TOC-5000A fitted with a ASI-5000A autosampler (TOC;

219 Shimadzu, Japan). Another set of triplicate $3.5 \mathrm{~g}$ subsamples was subjected to

220 fumigation. These were placed in open vials in a vacuum box, together with $25 \mathrm{ml}$

221 ethanol-free chloroform and exposed for $24 \mathrm{~h}$ at room temperature in the dark.

222 Samples were then extracted using the same method for non-fumigated samples.

223 The difference between the two carbon concentrations in the fumigated and non-

224 fumigated soils was considered total microbial biomass carbon.

Dehydrogenase activity

228 As a proxy for soil microbial activity (Wlodarczyk, 2000), dehydrogenase activity

229 (DHA) was measured by quantifying the rate of reduction of triphenyltetrazolium

230 chloride (TTC) to triphenyl formazan (TPF) using a modification of the method

231 described in Alef (1995). $2 \mathrm{~g}$ fresh weight soil samples were weighed into sterile glass

232 vials in triplicate and mixed with $2 \mathrm{ml} 0.7 \% \mathrm{TTC}$ solution made by diluting $0.7 \mathrm{~g}$ TTC in

$233100 \mathrm{ml} 100 \mathrm{mM}$ Tris (pH 7.5). The samples were shaken on a rotary shaker for 30 
minutes and incubated in the dark for 24 hours at $30{ }^{\circ} \mathrm{C}$. TPF was extracted by adding

$23510 \mathrm{ml}$ methanol, and incubating at room temperature for 2 hours with regular

236 shaking. Samples were filtered through Whatman №1 filter paper and absorbance at

$237485 \mathrm{~nm}$ measured on a Multiskan GO Microplate Reader (Thermo Scientific, US).

238

239

Community-level physiological profile and functional diversity

Biolog EcoPlates ${ }^{\mathrm{TM}}$ (Biolog, CA) were used to generate community-level physiological profiles (CLPPs) based on the microbial communities' ability to utilise different carbon substrates. EcoPlates can be used to distinguish between communities from

245 different habitats (Gomez, Ferreras, \& Toresani, 2006). They contain 31 carbon 246 compounds designed to reflect some of those found in root exudates and soils (in

247 triplicate, plus triplicate controls). A redox-colourant of tetrazolium violet is present 248 in all wells, which undergoes irreversible colour change when a carbon compound is 249 metabolised. Functional diversity can be estimated by the range and extent of 250 carbon compound metabolised.

$2522.5 \mathrm{~g}$ of soil (dry weight equivalent) was diluted in $22.5 \mathrm{ml}$ of $0.85 \% \mathrm{NaCl}$ solution and 253 put on a rotary shaker for 30 minutes. Samples were allowed to settle for 10 minutes 254 before dilution to $10^{-2}$, and $140 \mu$ l of this suspension was used to inoculate each well 255 of the EcoPlates ${ }^{\mathrm{TM}}$. Absorbance at $590 \mathrm{~nm}$ was measured with a Multiskan GO 256 Microplate Reader, with initial absorbance taken immediately, and then every 24 257 hours for 16 days at which point there was no further change in absorbance. 
Statistical analyses

261

262

Microbial biomass and dehydrogenase activity were compared using analysis of variance (ANOVA) on GenStat (VSN International), with Fisher's least significant difference (LSD) for pairwise comparisons. Biomass and DHA data were log transformed to fit the assumptions of ANOVA. Differences between CLPP patterns of carbon substrate utilisation were visualized using nonmetric multidimensional scaling (NMDS) and tested with permutational analysis of variance (PERMANOVA) on PRIMER software (Clarke \& Gorley, 2006). Differences in functional diversity, number of functions, homogeneity of multivariate dispersion measures of CLPP were also undertaken in PRIMER. Probabilities for rejecting the null hypothesis below 0.05 were considered significant, and between 0.05 and 0.10 were considered marginally 272 significant.

\section{Results}

Soil microbial biomass

279 Restoration type had a significant impact on soil microbial biomass (ANOVA, $F=$ $28028.97, P<0.001)$. All treatments were significantly different (LSD, $P<0.05 ;$ Fig. 1A), 281 with the exception of stockpiled soil and biosolids-amended soils. Unmodified native 
soil contained the greatest microbial biomass, followed by VDT, then biosolidsamended soil and untreated stockpiled soil, the latter being an order of magnitude lower in microbial biomass carbon than the pristine soil (Fig. 1A).

\section{Soil dehydrogenase activity}

Dehydrogenase activity (DHA) significantly differed between treatments (ANOVA, $F=$ 11.39, $P<0.001$ ). Pairwise comparisons (LSD, $P<0.05$; Fig. 1B) showed that DHA was significantly lower in untreated stockpiled soil than in all other treatments. Activity in biosolids-amended soil did not differ from the unmodified site or VDT. However, VDT had significantly lower rates of DHA than did the unmodified soil. (Fig. 1B). Linear regression analysis (Fig. 1C) indicates that microbial biomass was not correlated with DHA treatment means $(n=4)$.

\section{Community level physiological profile and functional diversity}

\section{Restoration technique significantly affected CLPP of the microbial communities}

(PERMANOVA, $F=6.526, P<0.001 ;$ Fig. 2). Pairwise analyses indicate that VDT did not differ from unmodified soil or biosolids-amended soil, but biosolids did marginally differ from unmodified soil (PERMANOVA, $F=2.023 P=0.055$ ). CLPP of stockpiled soil differed significantly from all other treatments (PERMANOVA, $P<$ 0.05; Fig. 2). 
307 Richness and Shannon diversity index of CLPPs significantly differed between

308 treatments (ANOVA, $\left.F_{\text {richness }}=25.00, F_{\text {diversity }}=15.51, P<0.001\right)$, where biosolids-

309 amended soils, VDT and unmodified soils did not differ from one another, but all

310 were significantly more rich and diverse than untreated stockpiled soil. Dispersion of

311 CLPP (the distance of points from the centroid within a treatment (Fig. 2), i.e.,

312 variation between samples within a treatment) also differed between treatments

313 (PERMDISP, $F=7.898, P=0.026$ ). Biosolids-amended soil did not differ from

314 unmodified soil, while VDT had marginally higher dispersion (PERMDISP, $F=2.848, P$

$315=0.061)$. VDT and biosolids-amended soils did not differ, but all restoration

316 techniques and unmodified soils were significantly less dispersed than untreated

317 stockpiled soil (Fig. 2).

\section{Discussion}

322 Soil microbial communities can be useful early indicators of restoration success

323 when assessment of plant colonisation or other ecosystem functions may not be

324 suitable or possible (Sparling, 1992; Harris, 2003; Gomez et al., 2006). Short-term

325 monitoring in this study indicates that VDT and biosolids addition consistently

326 restored all measured facets of the soil microbial community towards that of the

327 reference state. Previous work has found strong differences in soil chemical

328 properties between soil from different restoration methods on Stockton mine

329 (Waterhouse, Boyer, Adair, \& Wratten, 2014). The differences observed between 
restoration types in this study, therefore, are likely to be due in part to differences in soil physical and chemical properties arising from how the soil was treated following excavation (Abdul-Kareem et al., 1984) and from biosolids use (Sullivan, Stromberger, Paschke, \& Ippolito, 2005). Input of restoration resources beyond that of spreading untreated stockpiled tailings and replanting them with native vegetation was beneficial to the aspects measured in this study. VDT was the most effective protocol for restoring microbial biomass and activity as well as preserving a community composition somewhat similar to native sites. Biosolids amendments generally gave intermediate results and stockpile soils were least effective for restoration. The same order is followed for labour and financial burden. On the whole, our results suggest that such improvements are proportional to the effort and cost incurred for each restoration technique, i.e., VDT is the most costly, both in effort and financially, but restores microbial biomass, CLPP and functional diversity more effectively than do the other techniques.

VDT is a process that relocates areas of intact native ecosystem and therefore is an ecosystem that has experienced, and is recovering from, an extreme disturbance event. This may explain the reduction in microbial biomass and DHA compared to the undisturbed habitat (Peacock, Macnaughton, \& Cantu, 2001; Lucas-Borja \& Bastida, 2011), and further study would be required to establish if these measures of microbial communities return to pre-disturbance conditions in the long-term. Nevertheless, the current assessment suggests that VDT is the most effective restoration method deployed at Mt Frederick. In contrast, restoring areas with stockpiled soils and stockpiled soils mixed with biosolids are examples of habitats 
that are being engineered from scratch. For these habitats, measurements in this study are indicative of whether restoration is accelerating ecosystem development rather than recovery from disturbance per se. Biosolids have been successfully used to restore microbial communities on copper (Gardner, Broersma, \& Naeth, 2010) and coal (Evanylo, Abaye, Dundas, Zipper, Lemus, et al., 2005) mines, and in metalcontaminated mine tailings (Brown, Henry, Chaney, \& Compton, 2003), and comparing soils that were amended with biosolids with those that were not shows that the addition of biosolids leads to an acceleration of restoration in the majority of microbial measures in this study.

Although microbial biomass significantly differed between VDT and biosolids-treated stockpile soils, DHA, CLPPs, dispersion and functional diversity did not. The aim of carbon utilisation profiles in this study was not to compare community species composition (Bossio \& Scow, 1998), but to assess whether the communities have similar functional diversity and physiological profiles (Garland \& Mills, 1991), and comparing these to an unmodified native habitat can provide a useful measure of restoration success (Ruiz-jaen et al., 2005). The results in this study indicate firstly that some input of restoration effort beyond re-spreading and planting stockpiles is necessary for recovery of microbial CLPPs, dehydrogenase activity and microbial biomass carbon; and secondly, that biosolids addition and particularly VDT are especially effective for restoring such functions on the studied site. For example, both VDT and biosolids reduced the dispersion of CLPPs, resulting in communities more similar for plots within those treatments (Fig. 2), producing a similar homogeneity in communities between plots as in the unmodified habitats. 
Furthermore, richness and functional diversity based on CLPPs was significantly increased from untreated stockpiled soils to levels similar to unmodified soils. As VDT is a relatively recently deployed restoration protocol on the Stockton mine, this is an important finding showing that microbial activity and functional diversity are not substantially decreased upon relocation of the VDT sods from unmodified areas. The availability of carbon can have considerable effects on microbial communities (Bossio \& Scow, 1995), which may explain why the addition of biosolids, containing high levels of carbon, increased CLPP, functional diversity and activity substantially compared to stockpiled soil alone (Sharma, Rangger, von Lützow, \& Insam, 1998; Gomez et al., 2006; Zhang et al., 2012).

Dehydrogenase activity at VDT sites were lower than would be expected for the given biomass, and vice versa for biosolids-treated soil (Fig. 1c). However, similar functional diversity, richness and CLPP in the two treatments suggests that in biosolids-treated soil either a larger proportion of the soil microbial biomass in biosolids was active, or the same proportion was more active and more efficient at carbon substrate utilization under the conditions used in this study (Haynes \& Fraser, 1998).

Soil microbes mediate key ecosystem functions such as nutrient cycling and organic matter decomposition, which can in turn influence plant community assembly (Zhang et al., 2011). In the restoration methods employed at Mt Frederick, biosolidsamended soils and stockpiled soil spreads are often planted with similar planting schedules of native plants placed approximately $1 \mathrm{~m}$ apart, and when VDT is 
402

403

404

405

406

407

408

409

410

411

412

undertaken, gaps can develop between sods caused by mechanical damage, vegetation dieback, edge erosion and misalignment. Soil quality will be a key determinant in the recolonisation of gaps in planting schedules and between sods by immigrants and subsequent generations. Therefore, organic matter amendment (for example biosolids), should be considered in order to accelerate ecological succession in such gaps by ensuring that soil microbial communities have been adequately restored (Harris, 2009).

The microbial methods (Biolog EcoPlates, DHA, soil microbial biomass carbon) used to assess soil activity, functional diversity and CLPP throughout this work are subject to some limitations. For example, use of Biolog EcoPlates is a coarse method restricted to carbon substrates and lab-culturability of field microbes (PrestonMafham, Boddy, \& Randerson, 2002; Campbell, Chapman, Cameron, Davidson, \& Potts, 2003) and DHA is considered a proxy for general soil activity (Wlodarczyk, 2000). All of these methods were employed as measures for relative comparison between sites within the study, and not as absolute measures of soil microbial community (Preston-Mafham et al., 2002). In spite of the broad nature of rapid CLPP assessment tools (Lalor, Cookson, \& Murphy, 2007) these assessments yielded some interesting results distinguishing between treatments and agreeing with the benefits of restoration to microbial communities that has been observed in previous studies (e.g. Sullivan et al. 2005; Rojas-Oropeza et al. 2010; Zhang \& Chu 2012). However, variations in microbial community composition can cause substantial differences in function (Strickland, Lauber, Fierer, \& Bradford, 2009). Therefore the differences in community similarity for soil microbes may affect soil processes not measured in this 
study. Assessment of additional soil functions (e.g. decomposition, nutrient cycling

427 etc.) should be considered in future work, and over longer time periods to assess

428 long-term recovery.

429

430

431 Conclusion

432

433 Using soil microbial communities as early indicators of restoration success in this

434 study indicates that on the studied site these communities have benefited from

435 channeling resources into ecological restoration, including VDT and the addition of

436 biosolids to stockpiled soils, rather than replanting in untreated stockpile spreads.

437 Biosolids have received substantial research attention in the context of ecological

438 restoration, and the results of this study tend to agree with those of others, finding

439 beneficial effects on the microbial community. VDT, however, has not yet been

440 implemented globally or on a large scale, and yet shows great promise for ecological

441 restoration. Ongoing assessment is required to ensure that this recovery is

442 consistently benefitting soil functions, followed by assessment of other ecosystem

443 processes (plant and animal recolonisation, biomass production etc.) to quantify

444 further advanced recovery in the coming years. In the meantime, utilising the

445 responsiveness of microbial communities can be a valuable tool in monitoring early

446 recovery of ecosystems following mining. 
451 This study was undertaken on an active opencast coal mine and the authors are

452 grateful to Solid Energy New Zealand Ltd and Stockton Alliance for logistical

453

454

assistance and mine access and MBC Consulting Ltd for mine escort and sampling

assistance. The project was principally funded by the Miss E. L. Hellaby Indigenous

Grassland Research Trust, with additional financial support from Solid Energy New

Zealand Ltd and the Bio-Protection Research Centre.

\section{References}

Abdul-Kareem, A. W., \& McRae, S. G. (1984). The effects on topsoil of long-term storage in stockpiles. Plant and Soil, 76, 357-363.

Alef, K. (1995). Dehydrogenase activity. Methods in Applied Soil Microbiology and Biochemistry. Academic Press, London.

Bossio, D., \& Scow, K. (1995). Impact of carbon and flooding on the metabolic diversity of microbial communities in soils. Applied and Environmental Microbiology, 61, 4043-4050.

Bossio, D., \& Scow, K. (1998). Impacts of carbon and flooding on soil microbial communities: phospholipid fatty acid profiles and substrate utilization patterns. Microbial Ecology, 35, 265-78.

Boyer, S., Wratten, S., Pizey, M., \& Weber, P. (2011). Impact of soil stockpiling and mining rehabilitation on earthworm communities. Pedobiologia, 54, S99-S102.

Brown, S., Henry, C., Chaney, R., \& Compton, H. (2003). Using municipal biosolids in combination with other residuals to restore metal-contaminated mining areas. Plant and Soil, 249, 203-215.

Campbell, C. D., Chapman, S. J., Cameron, C. M., Davidson, M. S., \& Potts, J. M. (2003). A rapid microtiter plate method to measure carbon dioxide evolved from carbon substrate amendments so as to determine the physiological profiles of soil microbial communities by using whole soil. Applied and Environmental Microbiology, 96, 3593-3599.

Clarke, K. R., \& Gorley, R. N. (2006). PRIMER v.6: User Manual/Tutorial. PRIMER-E, Plymouth, UK.

Emmerling, C., Liebner, C., \& Haubold-Rosar, M. (2000). Impact of application of organic waste materials on microbial and enzyme activities of mine soils in the Lusatian coal mining region. Plant and Soil, 129-138. 
Evanylo, G. K., Abaye, A. O., Dundas, C., Zipper, C. E., Lemus, R., et al. (2005). Herbaceous vegetation productivity, persistence, and metals uptake on a biosolids-amended mine soil. Journal of Environmental Quality, 34, 1811-1819.

Gardner, W., Broersma, K., \& Naeth, A. (2010). Influence of biosolids and fertilizer amendments on physical, chemical and microbiological properties of copper mine tailings. Canadian Journal of Soil Science, 90, 571-583.

Garland, J., \& Mills, A. (1991). Classification and characterization of heterotrophic microbial communities on the basis of patterns of community-level sole-carbonsource utilization. Applied and environmental microbiology.

Gomez, E., Ferreras, L., \& Toresani, S. (2006). Soil bacterial functional diversity as influenced by organic amendment application. Bioresource Technology, 97, 1484-1489.

Grant, C., \& Ward, S. (2007). Return of ecosystem function to restored bauxite mines in Western Australia. Restoration Ecology, 15, 94-103.

Harris, J. (2003). Measurements of the soil microbial community for estimating the success of restoration. European Journal of Soil Science, 801-808.

Harris, J. (2009). Soil microbial communities and restoration ecology: facilitators or followers? Science, 325, 573-574.

Harris, J. A., Birch, P., \& Short, K. C. (1989). Changes in the microbial community and physico-chemical characteristics of topsoils stockpiled during opencast mining. Soil Use and Management, 5, 161-168.

Haynes, R., \& Fraser, P. (1998). A comparison or aggregate stability and biological activity in earthworm casts and undigested soil as affected by amendment with wheat or lucerne straw. European Journal of Soil Science, 49, 629-636.

Izquierdo, I., Caravaca, F., Alguacil, M. M., Hernández, G., \& Roldán, a. (2005). Use of microbiological indicators for evaluating success in soil restoration after revegetation of a mining area under subtropical conditions. Applied Soil Ecology, 30, 3-10.

Lalor, B. M., Cookson, W. R., \& Murphy, D. V. (2007). Comparison of two methods that assess soil community level physiological profiles in a forest ecosystem. Soil Biology and Biochemistry, 39, 454-462.

Lucas-Borja, M., \& Bastida, F. (2011). The effects of human trampling on the microbiological properties of soil and vegetation in Mediterranean mountain areas. Land Degradation \& Development, 394, 383-394.

Ohsowski, B. M., Klironomos, J. N., Dunfield, K. E., \& Hart, M. M. (2012). The potential of soil amendments for restoring severely disturbed grasslands. Applied Soil Ecology, 60, 77-83.

Peacock, A., Macnaughton, S., \& Cantu, J. (2001). Soil microbial biomass and community composition along an anthropogenic disturbance gradient within a long-leaf pine habitat. Ecological Indicators, 1, 113-121.

Preston-Mafham, J., Boddy, L., \& Randerson, P. F. (2002). Analysis of microbial community functional diversity using sole-carbon-source utilisation profiles - a critique. FEMS Microbiology Ecology, 42, 1-14.

Rojas-Oropeza, M., Dendooven, L., Garza-Avendaño, L., Souza, V., Philippot, L., et al. (2010). Effects of biosolids application on nitrogen dynamics and microbial structure in a saline-sodic soil of the former Lake Texcoco (Mexico). Bioresource Technology, 101, 2491-2498. 
Ros, M., Hernandez, M. T., \& García, C. (2003). Bioremediation of soil degraded by sewage sludge: effects on soil properties and erosion losses. Environmental Management, 31, 741-7.

Ross, C., Simcock, R., \& Williams, P. (2000). Salvage and direct transfer for accelerating restoration of native ecosystems on mine sites in New Zealand. In New Zealand Minerals and Mining Conference Proceedings

Ruiz-jaen, M. C., \& Aide, T. M. (2005). Restoration success: how is it being measured? Restoration Ecology, 13, 569-577.

Sharma, S., Rangger, A., von Lützow, M., \& Insam, H. (1998). Functional diversity of soil bacterial communities increases after maize litter amendment. European Journal of Soil Biology, 34, 53-60.

Sheoran, V., Sheoran, A., \& Poonia, P. (2010). Soil Reclamation of Abandoned Mine Land by Revegetation: A Review. Journal of Soil, Sediment and Water, 3, Article 13.

Simcock, R., Toft, R., Ross, C., \& Flynn, S. (1999). A case study of the cost and effectiveness of a new technology for accelerating rehabilitation of native ecosystems. In Prceedings of the 24th Annual Minerals Council of Australia Environmental Workshop (pp. 234-251).

Society for Ecological Restoration. (2013). http://www.ser.org/resources/resourcesdetail-view/ecological-restoration-a-means-of-conserving-biodiversity-andsustaining-livelihoods.

Sparling, G. (1992). Ratio of microbial biomass carbon to soil organic carbon as a sensitive indicator of changes in soil organic matter. Australian Journal of Soil Research, 30, 195.

Strickland, M. S., Lauber, C., Fierer, N., \& Bradford, M. A. (2009). Testing the functional significance of microbial community composition. Ecology, 90, 44151.

Sullivan, T. S., Stromberger, M. E., Paschke, M. W., \& Ippolito, J. A. (2005). Long-term impacts of infrequent biosolids applications on chemical and microbial properties of a semi-arid rangeland soil. Biology and Fertility of Soils, 42, 258266.

Vance, E., Brookes, P., \& Jenkinson, D. (1987). An extraction method for measuring soil microbial biomass C. Soil biology and Biochemistry, 19, 703-707.

Waterhouse, B. R., Boyer, S., Adair, K. L., \& Wratten, S. D. (2014). Using municipal biosolids in ecological restoration: What is good for plants and soil may not be good for endemic earthworms. Ecological Engineering, 70, 414-421.

Wlodarczyk, T. (2000). Some of aspects of dehydrogenase activity in soils. International Agrophysics, 14, 365-376.

Wortley, L., Hero, J.-M., \& Howes, M. (2013). Evaluating Ecological Restoration Success: A Review of the Literature. Restoration Ecology, 1-7.

Zhang, H., \& Chu, L. M. (2012). Early Development of Soil Microbial Communities on Rehabilitated Quarries. Restoration Ecology, 21, 490-497.

Zhang, H., \& Chu, L. (2011). Plant community structure, soil properties and microbial characteristics in revegetated quarries. Ecological Engineering, 37, 1104-1111. 


\section{Figure legends}

2

3 Fig. 1: A) Soil microbial biomass ( $\pm S E)$; (B) soil dehydrogenase activity (DHA) $( \pm S E)$;

4 (C) DHA ( \pm SE) was not correlated with microbial biomass $(r=0.742, F=5.75, P=$

$5 \quad$ 0.139). Unmodified native habitat $(\boldsymbol{\Delta})$, VDT $(\square)$, biosolids-amended soils $(\Delta)$ and

6 untreated stockpiled soil $(\bigcirc)$.

7

8 Fig. 2: Nonmetric multidimensional scaling (NMDS) plot based on Bray-Curtis

9 similarities of carbon substrate utilisation patterns: unmodified native habitat ( $\mathbf{A}$ ),

10 vegetation direct transfer (VDT) $(\square)$, biosolids-amended stockpiled soil ( $\nabla$ ),

11 untreated stockpiled soil (O). Unmodified and VDT patterns did not differ, biosolids-

12 amended soil and VDT did not differ, but biosolids did differ marginally from

13 unmodified soil. All other pairwise comparisons significantly differed. Stress 0.15.

14

15 
Figure 1:

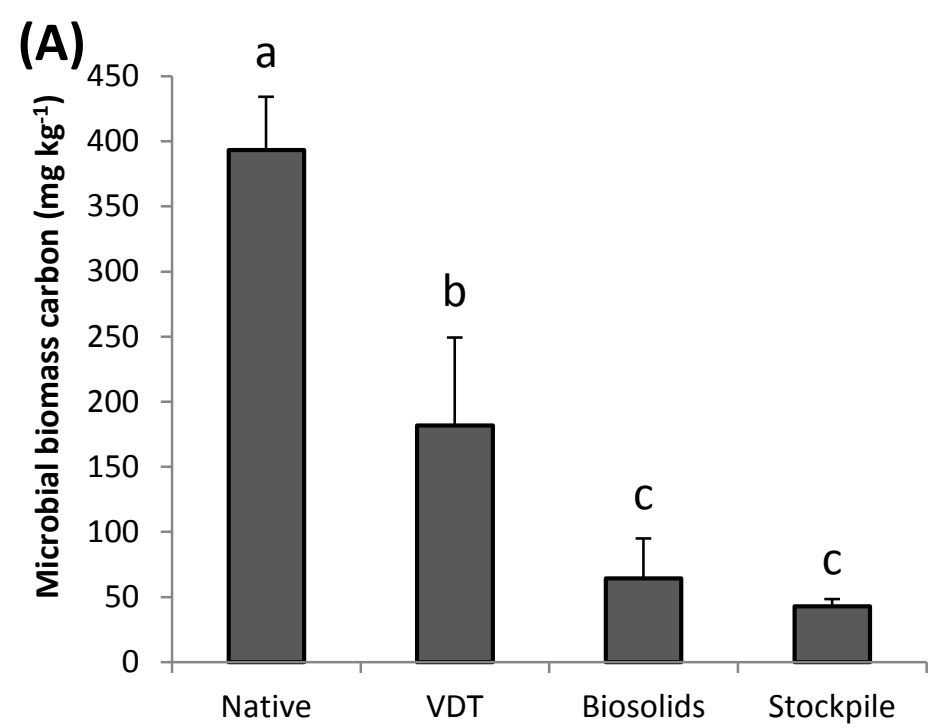

17

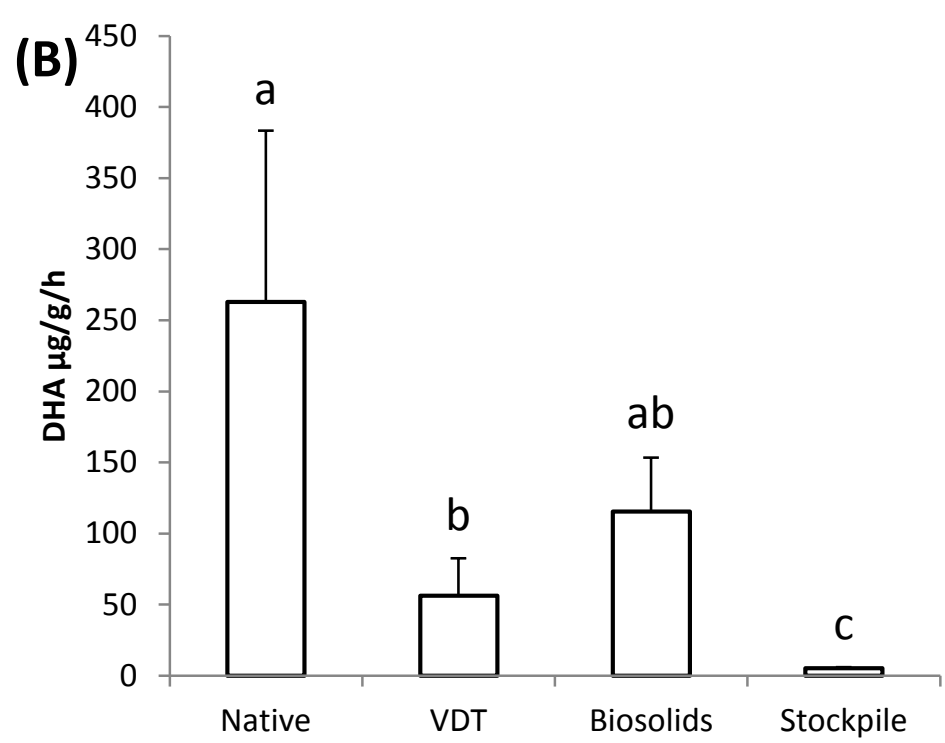

18

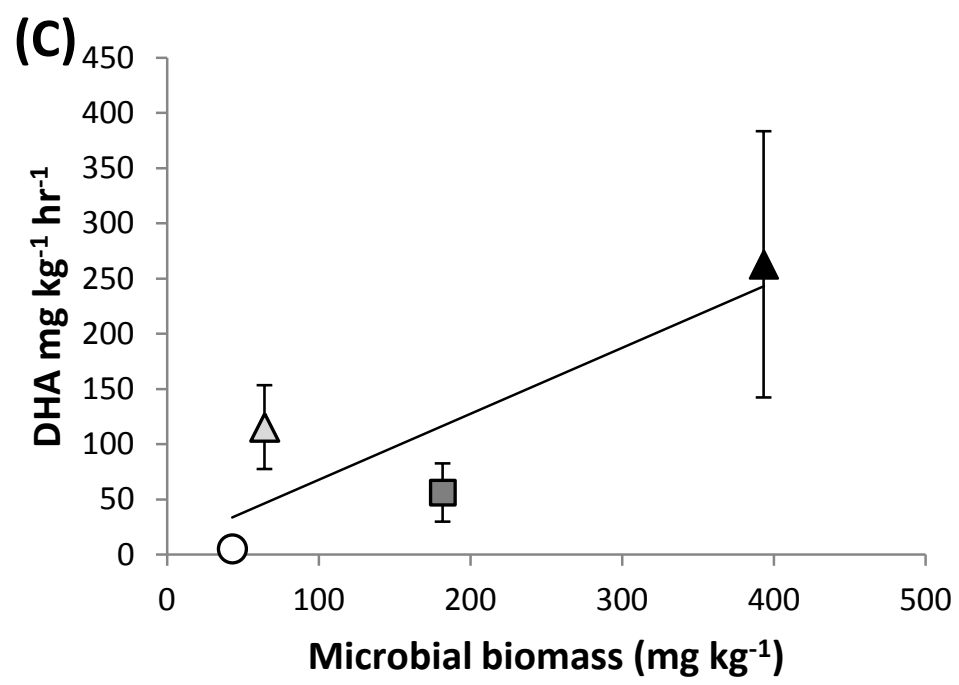


Figure 2:

21

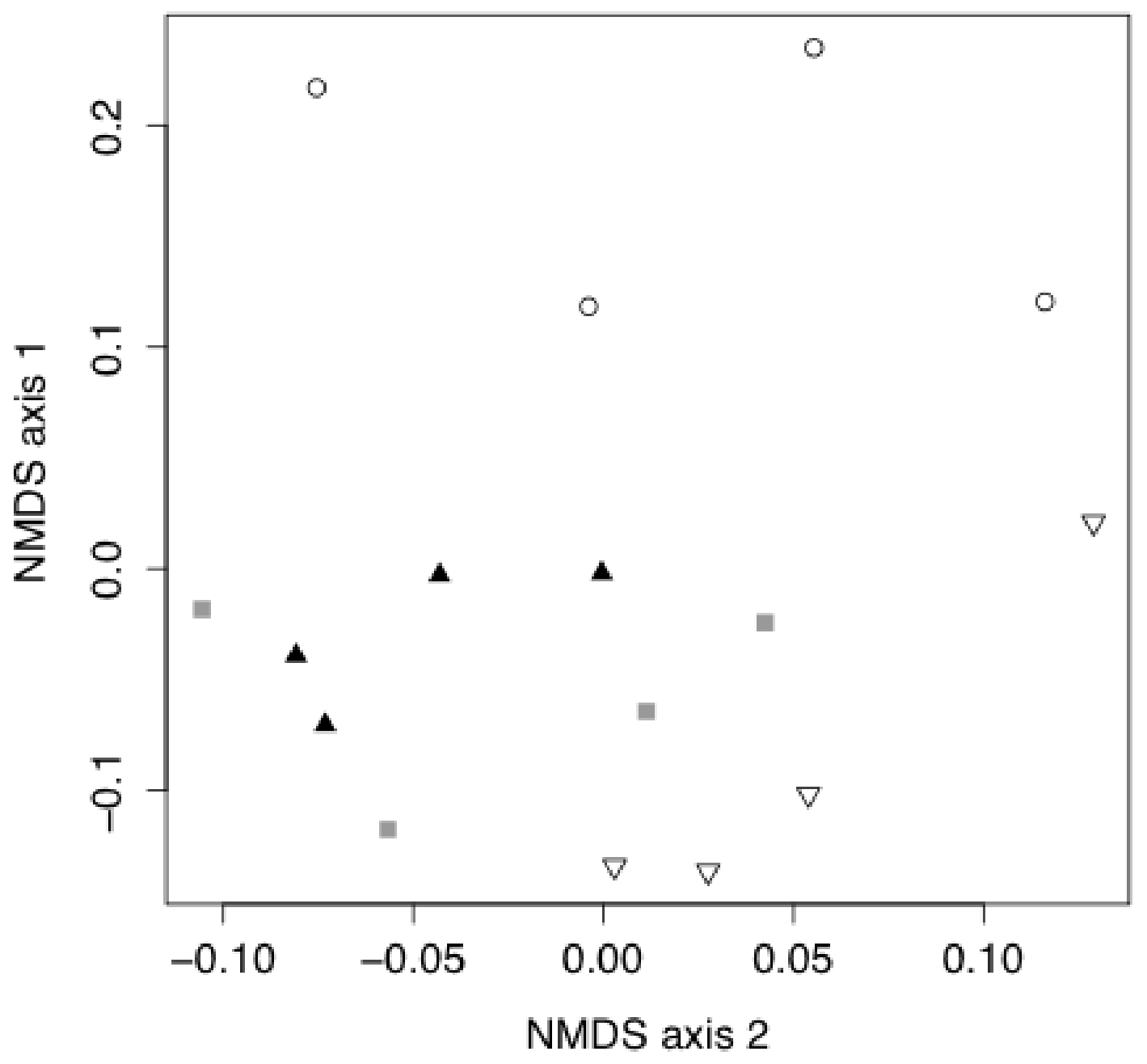

22

23 